\title{
Possible Morainal Deposits in the Gulf of Maine*
}

\author{
REGINALD N. HARBISON \\ Environmental Science Services Administration, Atlantic Oceanographic \\ Labor atories, Miami, Florida.
}

$\underline{\text { Introduction }}$

A detailed hydrographic, seismic reflection and magnetic survey was conducted by the USC\&GSS EXPLORER in the northeastern Gulf of Maine (Area A) along with an additional $1250 \mathrm{~km}$ of reconnaissance lines west of Area A (Fig. 1). Bathymetric, bedrock, isopachous and total magnetic field intensity maps have been prepared for Area A (Malloy and Harbison, 1966). A 160 -joule sparker provided the sound energy for the seismic work, and reflected signals were recorded on a dual-channel recorder. Frequencies were recorded between 300 and $600 \mathrm{Herta}$ on one channel and 600 to 1200 on the other. Raydist was used for navigational control in Area A (Malloy et al. , 1964).

\section{Discussion}

Throughout Area A a general northeast-southwest topographic trend prevails in the bedrock in the form of ridge and valley morphology. Seismic reflection profiles do not reveal any stratification within the bedrock which has been interpreted to be folded crystalline rock of Paleozoic age, overlain in part by Triassic formations (Malloy and Harbison, 1966). The bedrock is overlain by acoustically transparent sediments varying from 0 to $65 \mathrm{~m}$ in thickness. Bedrock valleys contain closed lows along their thalwegs, which suggest glacial erosion and there are many sediment blocked valleys which are probably caused by glacial outwash. Evidence for extensive glaciation in the Gulf of Maine has been presented by using seismic reflection data (Uchupi, 1966).

Unusual shadow zones on the seismic reflection profiles, apparently caused by areas of reverberated sound, occur in some places within the otherwise acoustically-transparent sediments. These zones of apparent reverberation have an appearance similar to the deep scattering layer on a fathogram, but are more intense and often mask out much of the bedrock surface below. The shadow zones are equally visible on both channels of the seismic reflection records with no obvious hyperbolic reflections. Many of these shadow zones are present within acoustically transparent sediments with their surface convex upward (Fig. 2).

Geographically, these shadow zones form predominantly sub-bottom ridges which are concentrated along a belt $14 \mathrm{~km}$ wide. This belt is centered on the $90 \mathrm{~m}$ isobath which is approximately parallel to the coast and is 30 to $40 \mathrm{~km}$ offshore (Fig. 3). These ridges average between 45 to $50 \mathrm{~m}$ in height above the bedrock and are located in water depths of 70 to $185 \mathrm{~m}$. They often appear to be eroded level with the sea floor and are ponded by acoustically transparent sediment which is probably clay. The ridges are not continuous features throughout the area.

King (1969) reports an end moraine complex on the Scotian Shelf about 30 to $40 \mathrm{~km}$ off the coast. He describes this end moraine complex as a belt of low discontinuous ridges which are to a large degree sub-bottom features masked by ponded clay and silt deposits. He states that these ridges are on the average $50 \mathrm{~m}$ in height above the underlying bedrock and lie in water depths ranging from 70 to $200 \mathrm{~m}$. He describes the dominant textural grade of the moraines as sand, but mentions that rock fragments in the gravel range are also present.

The Scotian Shelf end moraines are comparable to the ridges revealed by the shadow zones in the Gulf of Maine. The Gulf of Maine ridges are not found to extend above the sea floor as those on the Scotian Shelf sometimes do.

\section{Conclusions}

Shadow zones on the seismic reflection profiles are interpreted as graphic records of deposits of small-sized glacial debris surrounded by a matrix of acoustically transparent 


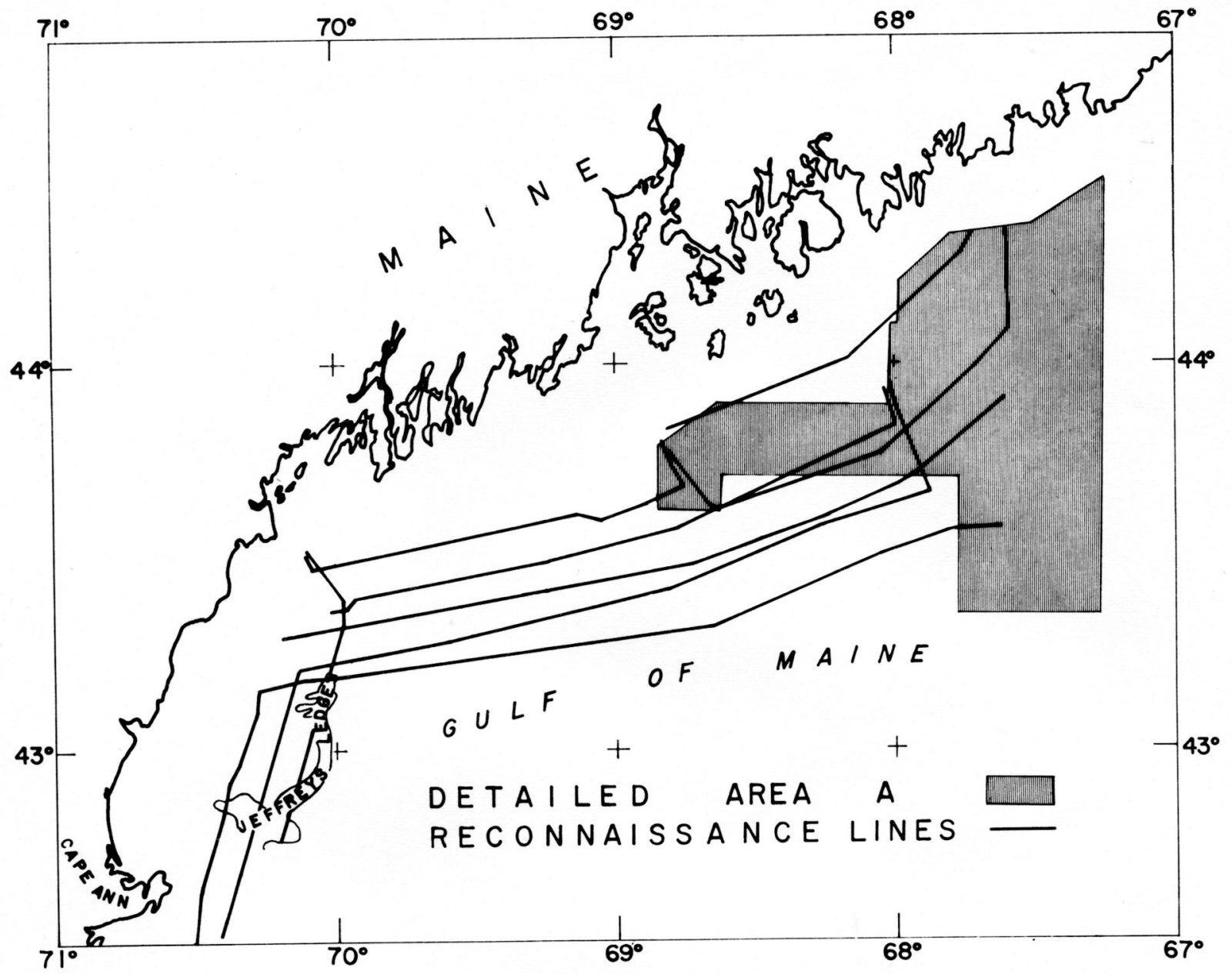

Fig. I Location of detailed survey area and reconnaissance lines in the Gulf of Maine.

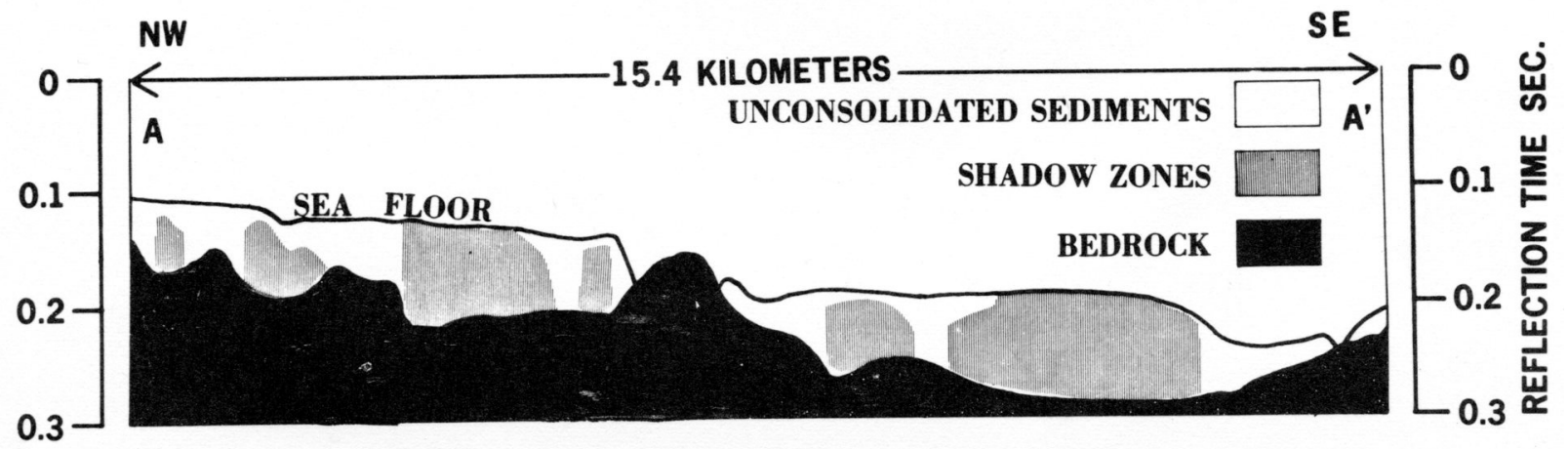

Fig. 2 A tracing of a seismic reflection profile across shadow zones. Profile AA' is located in Figure 3. 


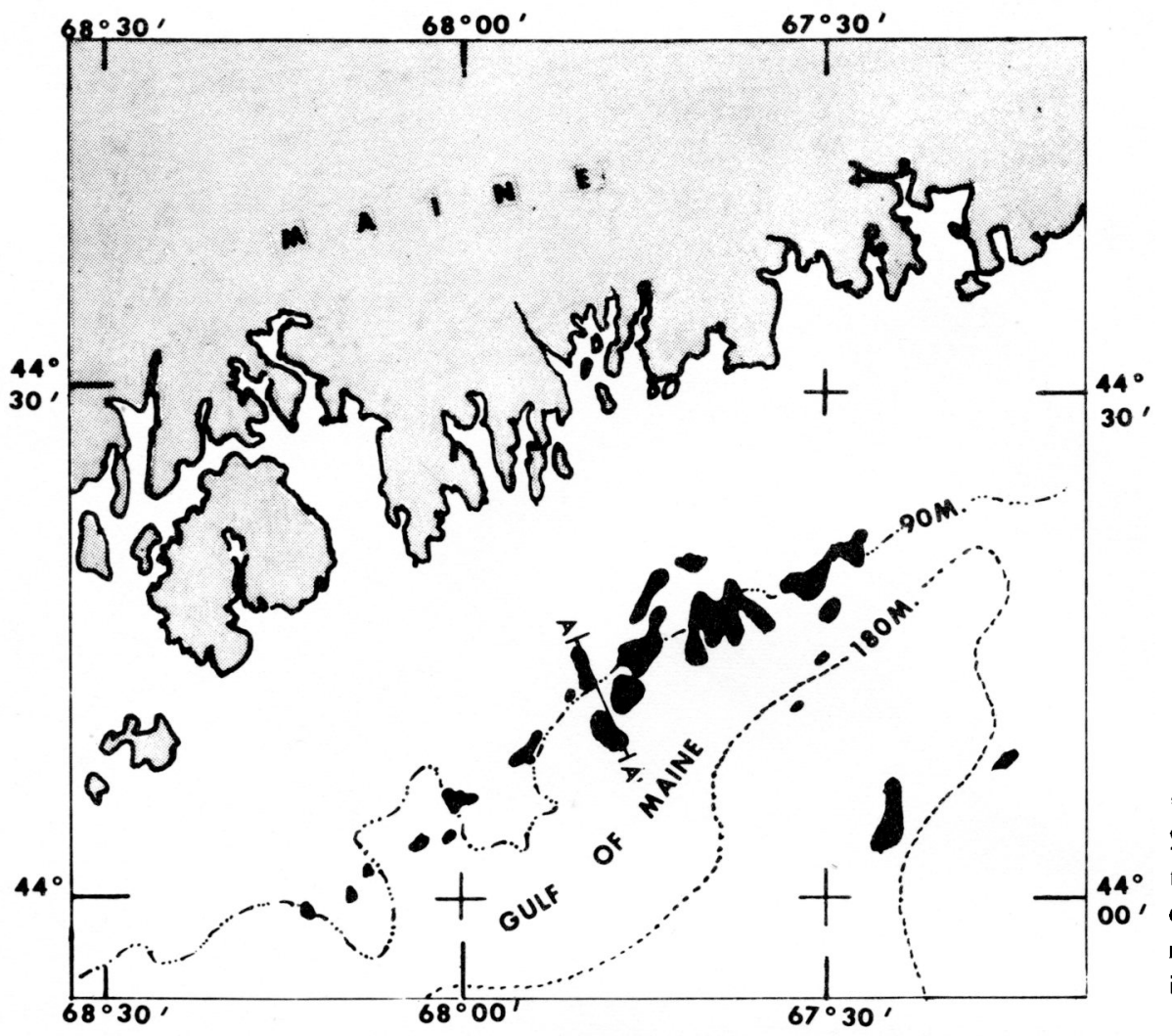

Fig. 3

Shadow zones, or zones of reverberated sound which interpreted to be an end morain complex are indicated in black.

sediment. The glacial material probably reverberates sound energy in the acoustically transparent sediments in the same manner that concentrations of small marine organisms reverberate sound in water as found in association with the deep scattering layer.

In areas where shadow zones are present, closed bedrock lows and maximum sediment thickness occur together. The closed bedrock lows are attributed to glacial erosion. Areas of maximum thickness are interpreted to be associated with an area of glacial stillstand. The absence of these shadow zones to the south and their concentration along a $14 \mathrm{~km}-$ wide belt in the vicinity of the $90 \mathrm{~m}$ isobath may indicate a former glacier-shoreline contact.

The Passadumkeag topographic sheet (USGS) for southeastern Maine shows sand and gravel morainal deposits extending to the present shoreline just north of Area A (Atwood, 1940). The shadow zones are in all probability a southern continuation of these morainal deposits.

The Gulf of Maine morainal deposits are interpreted to be gentle sub-bottom ridges of sand and gravel. These ridges are believed to be an end moraine complex similar to the one on the Scotian Shelf which they resemble in many ways.

\section{References cited}

ATWOOD, W. W, 1940, The physiographic provinces of North America, Ginn and Company, Boston, $536 \mathrm{pp}$.

KING, L.H., 1969, Submarine end moraines and associated deposits on the Scotian Shelf, Geol. Soc. of Amer. Bull., 80, 83-111.

MALLOY, R. J., HARBISON, R. N., and KEARSE, C. D., 1964, U. S. Coast and Geodetic Survey geological echo profiling program, International Hydrographic Rev., 41, 37-44.

, 1966, Marine geology of the northeastern Gulf of Maine, Tech: Bull. No. 28, U.S. Coast and Geodetic Survey, 11-15.

UCHUPI, E., 1966, Structural framework of the Gulf of Maine, J. Geophys. Res. , 72 (13), 3013-3028. 